\title{
Vieira, a inquisição e o capital
}

\author{
Alcir Pécora
}

Perguntado se cuidou em suas culpas como nesta Mesa lhe foi mandado $e$ as quer acabar de confessar para descargo de sua consciência e bom despacho de sua causa.

Disse que não tinha culpas que confessar.

Os Autos do Processo de Vieira na Inquisição, $2^{\circ}$ exame

(...) quanto mais, sobre as grandes notícias, que diz que tem da Escritura, e Santos Padres, persiste nas opiniōes que eles rejeitam, por não deixarem com elas

porta aberta à introdução de erros, e esperanças judaicas, como \{ele declarante faz com\} evidente perigo de se perverterem os Cristãos Católicos \{e se confirmarem os Judeus em sua perfídia, e cegueira.\} (Idem, 24ํㅡㄹ

\section{0 processo inquisitorial de Vieira}

\section{Os antecedentes}

Z m novembro de 1656, quando Vieira se achava no Brasil, à frente das Já mais de dois ano depois, em abril de 59, Vieira envia uma carta à Rainha viúva, D. Luísa de Gusmão, através de seu confessor d. André Fernandes, Bispo nomeado do Japão, dando-lhe conta de alguns felizes prognósticos para a monarquia lusa. A partir de uma minuciosa exegese a que submete as trovas do Bandarra, popularíssimas à época da Restauração, Vieira enuncia em forma silogística a idéia de que a serem verdadeiras as profecias que continham, como o acerto de várias delas parecia demonstrar (em particular, o da Revolução de 1640, que devolveu a autonomia à monarquia portuguesa), então d. João IV haveria de ressuscitar a fim de cumprir 
feitos decisivos reservados a ele. Embora a carta fosse escrito privado, alguma notícia dela logo chegou à Inquisição lisboeta, que a mandou requerer ao confessor.

Além disso, desde o ano de 49, por variadas alegações, Vieira vinha sendo denunciado ao Tribunal: comentário de livros proibidos, proposições ofensivas ao Rei e à Corte por permitir escravidão em seus domínios, injúrias contra outras ordens religiosas etc., tudo diligentemente anotado pelo Santo Ofício, muito interessado em processá-lo. E não sem causa bem mais palpável: no decorrer dos anos 40, Vieira procurara demonstrar a d.João IV a conveniência de restringir-se drasticamente a ação do Santo Ofício, extinguindo-se o confisco dos bens dos cristãos-novos processados e obrigando-o a dar as suas denúncias "abertas e publicadas", isto é, com declaração do crime e dos acusadores. As modificações pareciam essenciais a Vieira não apenas pela justiça delas, mas também pela utilidade dos novos procedimentos: só assim julgava possível implementar o plano que ideara de restaurar as finanças do reino através do incentivo ao retorno dos judeus portugueses endinheirados que, temerosos da Inquisição, dispersavam-se pela Europa em busca de ares mais tolerantes. Decerto, apenas a proteção real impedia que, já desde essa época, o Tribunal não movesse processo contra Vieira.

As coisas, todavia, começam a mudar para pior na década de 60. Logo em 62, Vieira é expulso do Maranhão devido às intermináveis pendências com os moradores a propósito das liberdades do índio e do exclusivo governo jesuítico das missóes. De volta a Lisboa, Vieira, para pesar de seus adversários, é recebido com honras pela Rainha d. Luísa, que mantinha viva a admiração e favor que o falecido Rei sempre dispensara ao jesuíta. Contudo, em junho, encerra-se o período da regência que a Rainha tentara em vão dilatar. Assume seu filho, d.Afonso, sexto do nome, e entrega a chefia do governo ao Conde de Castelo Melhor, adversário da facção que estivera, até aí, mais próxima do trono brigantino. Vieira, ligado à rainha, e tendo já assinado uma nota pública de repreensão ao filho, é desterrado para o Porto e em janeiro do ano seguinte para Coimbra. Era quanto bastava para a Inquisição abrir o adiado processo contra ele. 


\section{Início do processo. Primeira fase: julho/1663-setembro/1665.}

A carta confiscada ao confessor fora em seguida enviada a Roma para ser qualificada e nove de suas proposições haviam sido consideradas, em diferentes graus, temerárias, escandalosas, injuriosas à Igreja, ofensivas a ouvidos pios e sapientes a heresia. Com este enorme trunfo em mãos, o Tribunal aperta o cerco: em julho de 63, Vieira é convocado a depor na Inquisição coimbrã. Interrogado sobre o conteúdo da carta, defende-se dizendo que a compusera "principalmente para alívio da senhora Rainha". Convocado posteriormente para uma segunda sessão, afirma que a ressurreição de d.João IV não era uma verdade que supunha infalível, mas provável, em se admitindo que o Bandarra era verdadeiro profeta, como o fizera, adotando a comum opinião do reino. Esboça-se aqui a sua principal linha de defesa ao longo de todo o processo, cara ao casuismo probabiliorista dos jesuítas, de que as afirmações feitas se justificariam não como enunciado verdadeiro, mas verossímil, admitidas as condições precisas de seu emprego. A esse argumento, Vieira acresce o de que, revelando-se falso o enunciado, como estava disposto a acatar tão logo o determinasse o Tribunal, isto caracterizaria erro, mas não culpa, dado que proferido sem "má tenção" contra a fé ou a Igreja, e, sim, ao contrário, por engano das circunstâncias e puro desejo de fortalecimento do reino e expansão católica. O jesuíta, além disso, insiste em que a censura das sentenças ignorou o verdadeiro sentido com que as proferiu e reivindica o direito de redigir uma defesa, explicando qual fosse ele. Assim, durante os exames, combinando esses argumentos, recusa-se a declarar culpa — se o fizesse, sem dúvida, teria abreviado o processo, como o advertiam os qualificadores, que provavelmente se dariam por satisfeitos com a submissão ou desqualificação pública de Vieira.

Concedido, com alguma hesitação, que explicasse as principais proposiçôes da Carta, Vieira refaz escritos de várias épocas a propósito de uma nova idade do Mundo, o V Império, que viria suceder o Romano, que se estendia até o presente. A novidade em relação à exegese tradicional do Apocalipse era a de que essa idade seria não apenas espiritual, mas temporal igualmente, e anterior ao tempo do Anticristo. Logo, o Império não se daria no breve interregno entre a vinda deste e o Juízo Final, mas dilatar- 
se-ia por um período em que, tendo como principal instrumento um rei português, seria destruído o Turco e restaurada a monarquia cristã universal, com o reaparecimento das tribos perdidas de Israel, reconversas e conduzidas às suas terras; então os homens viveriam longamente em paz. Essa a direção salvífica a que Vieira busca acomodar Escrituras, Autores, profecias e fatos.

Vasta matéria! Passados dois anos, em que é obrigado a comparecer regularmente ao Santo Ofício, submetendo-se até então a nove exames, Vieira ainda não dá por encerrada a sua defesa, alegando sucessivos achaques, em que parece estar pela hora da morte a cada dia. Um exemplo dessas alegações, entre muitos, pode ser colhido na sessão de sábado pela manhã do dia 5 de abril de 64; Vieira apresenta ao Tribunal, em conjunto com seu procurador, uma solicitação em que pede aos qualificadores

(...) lhe façam misericórdia de lhe concederem o tempo necessário para dispor um papel em que dê a razão de todas as sobreditas coisas, representando que não poderá ser tanto em breve como ele deseja, visto andar ainda doente, e em cura de uma enfermidade tão larga, e perigosa, e tão contrária à aplicação do estudo como de haver lançado muito sangue pela boca $(. . .)^{1}$

Quando o Tribunal já não admite dilações, não falta o certificado do médico do Colégio dos Padres da Companhia, que também o era do Santo Ofício, datado de 16 de agosto de 65, a atestar:

(...) que o Padre Antônio Vieira residente no próprio Colégio, nos três anos, que nele tem estado, em todos eles adoeceu gravemente, com enfermidades muito rebeldes, e prolongadas, as quais com grande dificuldade obedeciam aos medicamentos, e agora esta última deste presente ano lhe tem durado a mor parte dele, com vários insultos de febre, sintomas, e acidentes diversos, que obrigaram a cura muito prolongada, e trabalhosa, não sem perigo de sua vida, a qual nestes ares está arriscada, por as doenças cada vez serem mais prolongadas, e mais intensas; o que entendo ser originado do sítio, e clima da dita cidade, e falta dos ares marítimos, em que o dito Padre foi sempre costumado a viver. ${ }^{2}$

Enfim, nesta altura do processo, parece certo que Vieira buscava meio de adiar a entrega da defesa até que os sucessos do reino, em turbulência, levassem a uma eventual suspensão do processo. Em setembro de 65, a 
Inquisição manda, de uma vez por todas, que entregue à Mesa, em qualquer estado, os papéis que vem compondo, mesmo sob o seu protesto veemente de que, no borrão em que se encontravam, "confusos e indigestos como deles se podia ver", não responde absolutamente por eles. ${ }^{3}$ Ao entregálos, contudo, não sossega. Sem os papéis que compusera até então e sem mais prazo de dilação da defesa, Vieira, em menos de uma semana, redige uma longa e imprudentíssima petição ao Conselho Geral do Tribunal de Lisboa, cujo encaminhamento mal e mal abafa sua indignação:

Custou-me cuspir de novo sangue o escrevê-lo com tal pressa: e parece que meu estado merecia compaixão quando não favor. ${ }^{4}$

A Petição, uma vez mais, dá conta de que as censuras tomam-no em sentido muito diverso de seu merecimento; que o Advogado que lhe fora designado não conhecia Teologia; que fora ameaçado e assinara por força o documento de compromisso de entrega de sua defesa até a Páscoa, quando se encontrava doente e incapaz de redigi-la; que fazia violência ao direito natural de defesa confiscarem-lhe os papéis cuja novidade da matéria mereceria até um Concílio inteiro. Em decorrência disso tudo, solicitava licença para convalescer próximo ao mar e dilação do prazo para redação de sua defesa, além da devolução dos papéis inconclusos seqüestrados; também requeria vista das proposições censuradas e declaração dos Autores que supostamente as impugnam, sob risco de ficar indefeso e não se fazer a justiça devida ao caso. Vieira requer ainda, de maneira quase inacreditável, que entre os qualificadores não sejam admitidos, por suspeitos de isenção, nem carmelitas, responsáveis por sua expulsão do Maranhão; nem dominicanos, por emulação da Companhia e má vontade pelo que pregara no Sermão da Sexagésima; nem ministros romanos, dado que os papéis falavam em castigos da Itália, felicidades de Portugal e ruína de Castela, e era notória a influência desta em Roma. Com certeza, a Petição não pode explicar-se por ignorância de Vieira de que o Tribunal fosse controlado pelos dominicanos, ou por imaginar que estes poderiam acatar a suspeição que formulava e ainda silenciá-la diante de Roma. Talvez pretendesse estabelecer uma desqualificação a priori dos juízos formulados a respeito dos papéis e denúncias, o que talvez lhe permitisse prosseguir a defesa mesmo 
quando viesse a condenação inevitável. Mais provável, porém, é que realmente não tenha sofrido o cabal desacato de sua condição de teólogo e religioso, com "quarenta anos de estudo" e larga folha de serviços prestados ao Rei e ao Reino: a conhecida altivez do seu ânimo certamente picouse aqui.

\section{Segunda Fase: outubro/1665-dezembro/1667}

Pois bem, a Petição é de 21 de setembro; o desastre vem a galope: a 25, o Conselho Geral de Lisboa determina que "seja o Réu chamado à Mesa do Santo Ofício e de aí mandado recolher em um dos cárceres da custódia”" da Inquisição coimbrã; em primeiro de outubro de 65, Vieira é encarcerado. Já no dia seguinte é recebido em audiência, que solicitara para saber a causa de sua prisão, e é-lhe revelado, pela primeira vez, passados mais de dois anos, que as censuras da Carta foram feitas em Roma pelos Qualificadores da Sagrada Congregação do Santo Ofício. Aqui, talvez pela primeira vez, pode-se surpreender alguma hesitação no jesuíta. Vieira reafirma que "está pela censura", mas pede procurador para aconselhar-se se deve insistir em sua defesa. Em novembro está novamente em forma: requer permissão oficial para prossegui-la e demonstrar que não teve "malícia" nos escritos.

Recluso e sem livros, ainda assim, Vieira atira-se à composição de seus papéis; em julho de 66, entrega as duas representações da Defesa Perante o Tribunal do Santo Oficio. ${ }^{6}$ Em outubro recomeçam os exames e concentram-se na "presunção de judaísmo", que, àquela altura, resumia o núcleo das censuras. Acusa-se Vieira de usar o V Império e seu Príncipe português como "coberta" para a expectativa do "Messias", e, ainda, de "justificação do erro judaico" pela tentativa de assegurar-lhe fundamentos teológicos "nos mesmos lugares e Autoridades da Escritura” utilizados pela Igreja Católica para demonstração da "perfídia" que havia nele. "Fino judaísmo", portanto, muito mais grave que o do Bandarra, já que proferido por homem douto.

Até março de 67, Vieira é interrogado treze vezes, neste mesmo ponto. Em abril, o exame incorpora como objeto de suas censuras a ousadia descomedida e injuriosa do réu, por "ódio, que tem aos Tribunais, e Ministros do Santo Ofício", tomando por base da acusação sobretudo os ter- 
mos da Petição de setembro de 65. A principal culpa, porém, segue a de deixar a "porta aberta à introdução de erros, e esperanças judaicas". No 260 e $27^{\circ}$ exames, o "amor ao judaísmo" de Vieira é exemplificado com o que os Inquisidores sempre tiveram em mente: os atos inspirados por ele com a finalidade de que d.João IV "chamasse a este Reino os Judeus" e suspendesse o confisco de seus bens, de modo a que vivessem "na lei que lhes parecer", desde que "sem perturbar a República, ou ofender o público", onde se contém "manifestamente os erros dos Maquiavelistas, Maniqueus, Calvinistas, e outros(...)" 7

Vieira, todavia, em nenhum momento admite culpa, como repete ao Inquisidor a cada início de exame, e anotam os notários em fórmula própria, com mínima variação no decorrer dos autos:

Disse que não tinha culpas que confessar, nem mais que declarar acerca da tençãa.

O jesuíta, através de sucessivas distinções, reafirma a disposição de submeter-se às censuras e admite a possibilidade de erro de interpretação, mas nega a má-fé e os sentidos anticatólicos em que as proposições vão sendo tomadas pelos qualificadores.

Em agosto, quando os exames não deixavam ver um fim próximo, dáse afinal a Vieira, passados já quatro anos, a notícia de que a censura às suas proposiçōes "foram expressamente aprovadas por Sua Santidade". Neste momento, aliás, as proposiçôes censuradas —, partidas, multiplicadas e acrescidas - já contam uma centena. Vieira, enfim, como escreve o notário do $28^{\circ}$ exame, "desiste não só de defender todas as sobreditas Proposições, ou qualquer delas (como nunca tratou de defender) mas ainda de as querer explicar, ou declarar o sentido delas, como até agora ia fazendo, no discurso deste seu processo." 8

O passo é bastante curioso. Parece que ao anunciar o conhecimento papal das censuras, a Inquisição achava meio de encerrar o arrastado processo através de uma espécie de deus ex machina, já que a censura emanava de uma autoridade superior infalível, e não da necessidade lógica dos autos, que não podia prescindir da confissão ou da prova da culpa do réu. $\mathrm{Na}$ verdade, a Inquisição estava mesmo interessada em dar cabo do processo, 
tanto devido ao fato de que não parecia ter fundo o arsenal das modalizaçōes de Vieira, suas "escusas" e "desvios", como escrevia o notário, quanto sobretudo ao de que a derrocada do governo de Afonso VI era já visivelmente irresistível. Logo no mês seguinte, este é obrigado a demitir o Conde de Castelo Melhor, e em seguida ele próprio é preso, num escandaloso golpe de Estado em que a sua mulher, d. Maria Francisca de Sabóia, alia-se ao cunhado mais novo, d. Pedro, que, em novembro, assume a Regência. Os antigos aliados e amigos de Vieira vão todos sendo reconduzidos ao poder e era óbvio que não tardaria alguma intromissão decisiva a seu favor. São feitas mais duas sessões a respeito de proposições encerradas em uma edição espanhola de alguns de seus sermões, mas os inquisidores não se demoram nos pontos refutados por ele, nem parecem mais incomodar-se com o fato de que, na matéria da confissão, segue dizendo "que não tinha culpas que confessar etc.". ${ }^{9}$ Em outubro, os autos são dados por concluídos.

Dia 23 de dezembro de 1667, a duríssima sentença é lida diante do réu na sala do Santo Ofício. Segundo o que se anota na edição incluída nas Obras Inéditas do Padre Antonio Vieira, ${ }^{10}$ a sua leitura, pela tarde, dura mais de duas horas. É novamente lida, na manhã do dia seguinte no Colégio dos Jesuítas de Coimbra, estando presentes os de sua religião, que levantam-se todos, com o réu, para ouvi-la. ${ }^{11}$ Condena Vieira a ficar privado para sempre da "voz ativa e passiva", vale dizer, de exercer ou investir qualquer autoridade, e ainda do "poder de pregar"; proíbe-o também de tratar, em público ou privado, de quaisquer das proposiçóes censuradas, ficando recluso perpetuamente em casa jesuítica. Fixam-lhe inicialmente residência no Porto, depois no próprio Colégio de Coimbra e enfim no Noviciado de Lisboa, sítios progressivamente mais amenos, tudo por conta das influências favoráveis a Vieira emanadas da Corte. E não ficou nisto: seis meses depois, em junho de 68, recebido em audiência na casa da Inquisição em Lisboa, Vieira é perdoado de "todas as penas em que foi condenado na Inquisição de Coimbra, ficando somente em pé, e em seu vigor a obrigação que por termo por ele assinada fez de mais não tratar das proposições tratadas em sua sentença”. ${ }^{12}$ Evidentemente, o Santo Ofício reconhecia que a fortuna andava rodando favoravelmente a Vieira.

É este, em resumo, o roteiro dos autos. 


\section{A exegese do capital}

A leitura dos trinta autos do processo inquisitorial de Vieira deixa claro, para mim, que o Tribunal do Santo Ofício, nas diferentes qualificações acolhidas em Coimbra, acerta o alvo num ponto decisivo: aquele em que afirma que o jesuíta quer conciliar o judaísmo, ou a admissão de algumas de suas práticas, com lugares das Escrituras restritos à exegese católica, com o propósito de agradar ou favorecer sobretudo a expectativa dos judeus batizados. Isto está dito em muitos passos e matérias do processo, por exemplo, na censura mandada ajuntar a ele em 16 de julho de 1666, referindo o tema do VImpério:

Quem porém não verá que para muitos será plausível a proclamação de um tal reino milenário acima de todo o mundo com tanta paz temporal que ninguém resistirá temporalmente e o que é mais, com tanta paz espiritual que o Diabo não terá absolutamente nenhum mérito para então tentar os homens subjugado durante todo aquele milênio — em que por isso ensina quase todos os homens a se salvar. Isto agradará sobretudo verdadeiramente aos judeus a quem promete ver os seus que são da mesma tribo, restituídos em dez tribos irem com eles próprios para a terra das antigas promessas na maior soberba. Acima de tudo, porém, agradará aos judeus batizados a quem se diz que podem impunemente esperar o seu Messias contanto que exteriormente não falem ou procedam contra o Evangelho. ${ }^{13}$

$\mathrm{Ou}$, de maneira mais resumida, no Exame 27, onde se registra que Vieira queria "fazer \{lícitas, e\} compatíveis coisas entre si encontradas, como é o ser juntamente Judeu, e Cristão, a lei de Cristo, com a de Moisés, e as cerimônias de uma, e outra (...)". ${ }^{14}$

Tirante o malicioso das frases, parece-me que a fortuna crítica de Vieira, desde então, tem sido menos precisa na determinação desse objetivo fundamental — diria mesmo, inalienável —, de seus escritos, como é o de favorecer deliberadamente a acomodação de "esperanças judaicas" com tópicas escriturais utilizadas pela tradição hermenêutica para condená-las como "erro" e "perfídia". ${ }^{15}$ Apenas que, desta constatação, não se segue absolutamente a "má tenção" que, de maneira injusta, imputa-lhe o Tribunal. É rigorosamente absurdo supor, em Vieira, qualquer intenção dúbia em relação à fé ou à Igreja Católica, qualquer vontade herética "de se per- 
verterem os Cristãos Católicos \{e se confirmarem os Judeus em sua perfídia, e cegueira\}" (como se anota no Exame 24), ${ }^{16}$ desde que se tenha em mente o óbvio: a sua vida inteira dedicada às missōes nas brenhas do Brasil, a renovada obediência que sempre prestou à Companhia, mesmo nos momentos difíceis em que esteve ameaçado de ser expulso de seu grêmio, e, enfim, a persistente preocupação com a "missão cristã de Portugal" no mundo, entendida como esforço de criação de condições favoráveis ao fortalecimento do reino e à expansão universal da fé.

Mesmo na matéria controvertida do VImpério, o paraíso terreal iminente cujo anúncio julga poder ler nas Escrituras, nada nela contraditou jamais a aceitação do governo espiritual do Papa. Este fato, aliás, reconheceu-o a própria Inquisição portuguesa, em nova qualificação, de que foi relator Frei Teodósio da Cunha (1662-1742), doutor em Teologia, lente de Coimbra, e membro dos Eremitas de Santo Agostinho. ${ }^{17}$ Em documento datado de 25 de abril de 1729, dado à luz por Mário Nunes Costa, o agostiniano pronuncia-se da seguinte forma a respeito da eventual publicação da sentença da Inquisição e da apologia das proposições, escrita por Vieira, sobre a qual, em parte, recaíra a sentença:

Li por mandado de V.Sria. este manuscritto, em que se contem a sentença do Santo Officio dada contra o Pe. Antonio Vieyra da Compa. de Iesu, e lida publicamte. ao mesmo Pe. na sala do Santo Officio da cidade de Coimbra em 23 de dezembro de 1667; e juntamte. a Apologia das proposiçõis de que foy arguido o mesmo P. e sobre que cahio a sentença. E me parece que o tal manuscrito não contem couza alguma, por que deva ser prohibido (...). ${ }^{18}$

O parecer seguro de Frei Teodósio alivia Vieira das culpas denunciadas na sentença, e, na direção oposta, faz pesar sobre os qualificadores de suas proposiçóes a suspeita de rigor excessivo. Assim, referindo o comentário de Cornélio, A Lápide, sobre a de outros doutores, considera que também aquele, face à afirmação de uma futura

(...)paz, e felicide. prometida a Igra. em q $\sim$ não ha de haver heresias, ou inimigos que a perturbem, mas hu - a sandide. constante sem necesside. de reforma ha de durar por mil annos antecedtes. ao Antichristo, em q no Apocalypse se diz q $\sim$ ha de estar Satanaz preso pa. não tentar, ou perturbar os home $\sim$, não respeita esta opinião por heretica, ou erronea (...). ${ }^{19}$ 
Faz o mesmo com a questão da existência do VImpério, que não é suposição herética se concebido "distincto accidentaliter" e não "substantialer do 40"; ${ }^{20} \mathrm{e}$ ainda com a afirmação de que Rei português haja de ser o seu Imperador, o que, como diz,

(...) não me parece que merece censura alguma; e só a merecerá de proposição temerária, se affirmar isto absolutamte. e não so como sosppeyta, como opinião provavel, como parece queria o P. Vieyra (...). ${ }^{21}$

Também o afirmar Vieira que há de ressuscitar um Rei de Portugal, para ser instrumento da redução dos infiéis todos à fé de Cristo, não é, segundo o qualificador,

(...) proposição heretica, nem erronea, ou sapiens hoeresim, pois não he contradittoria de alguma proposição legitimamte. deduzida de huma de fe, e outra evidente, ou ao menos mui provavel", embora seja "temeraria por carecer de fundamto. grave. ${ }^{22}$

Mas nem é preciso chegar a isenção tão ampla de culpas. Está perfeitamente evidente nos papéis do processo de Vieira que não há nenhuma "má tenção" contra a Igreja ou a cristandade católica, nem há, como admite expressamente já o $2^{\circ}$ Assento do Santo Ofício, de 18 de outubro de 1667, que orientou a própria sentença condenatória, qualquer indício de prática de judaísmo de sua parte. O primeiro atenuante da sentença aí relatado, reza justamente que:

em todos esses autos, se não prova legitimamente contra o Réu, fazer ele, ou dizer coisa (alguma formalmente) herética, ou judaica, sobre que a suspeita, ou presunção acima dita de heresia, ou judaísmo \{possam assentar\} e vestirem-se daquelas qualidades que o direito requer, e aprova (...). ${ }^{23}$

Contudo, afora essa evidente distorção que há em querer fazer de Vieira um herético - ali, para perdê-lo, e em nossos dias, muitas vezes, para louválo como transgressor e libertário - , parece-me importante não perder de vista que as teses proféticas de Vieira desejam, resumidamente, isso mesmo que o Tribunal diagnostica: ser atraentes para os cristãos novos. Para usar uma analogia de proporção, eu diria: tais teses desejam ser tão atraentes para os cristãos novos, nas práticas do espírito, vale dizer, como fórmu- 
la de convivência mental com os católicos portugueses, quanto o poderia ser a isenção do confisco de seus bens, na matéria temporal. A afirmação profética do VImpério é parte essencial da argumentação de Vieira destinada a convencer os judeus de que deveriam retornar a Portugal e aqui empregar o seu cabedal, pois apenas a este Estado estava destinado um papel compatível com o futuro previsto por sua crença.

Assim, exemplarmente, Vieira concilia a vinda do Messias, e a conseqüente reunião dos judeus dispersos pelo mundo, com o aparecimento do Príncipe Encoberto português, fundador deste novo Império espiritual e também temporal, que possibilitaria a recondução da gente de nação às suas terras. As teses expostas na carta Esperanças de Portugal, Quinto Império do Mundo, dirigida à Rainha d. Luísa de Gusmão, em abril de 1659, e depois esmiuçadas, refundidas, modificadas, mas sobretudo sutilizadas, ao longo do processo inquisitorial, agem sempre na mesmíssima direção. É o que se pode ver na sessão em que Vieira admite ter dito

(...) que para convencer aos Judeus, não se lhes havia de negar absolutamente o poderem ainda ser restituídos à sua pátria; antes se lhes havia de provar com as Escrituras, que esta restituição, se a houvessem de ter, havia de ser por meio da Fé, não do Messias, que eles esperavam, senão do verdadeiro Messias Cristo IESU, que já veio. ${ }^{24}$

E tais provas escriturais acomodam-se perfeitamente, em seu discurso, a outras que descobrem correspondências entre as expectativas sebásticas, admitidas ou toleradas, e as judaicas, execradas pelo Tribunal. Assim, concede que:

(...) convertendo-se os ditos Judeus inteiramente à Fé do mesmo Cristo, tendo-o por verdadeiro Deus, e Messias prometido, não seria inconveniente conceder-lhes, que na suposição da dita Fé Católica, esperassem juntamente o ser restituídos ainda à sua pátria, por meio de alguma pessoa, da sua, ou de outra nação; assim como em Portugal, não encontra, nem encontrava a verdadeira Fé Católica dos Portugueses o esperarem muitos deles no tempo da sujeição de Castela, o haverem de ser eximidos dela, e restituídos a sua antiga liberdade, por meio de el-Rei Dom Sebastião, ou de outro Príncipe. ${ }^{25}$ 
Mas se assim é, ou parece, vale dizer, que a situação de risco da soberania justifica o ajuste de esperanças messiânicas, tanto mais manifesta, para Vieira, é a decorrência de que o instrumento fundamental para reparar-se o "estado miserável" do Reino, no temporal, sempre era o capital judeu. Não pelo seu montante apenas, que reputava contudo como sendo de "grande número de milhões", mas também pelo talento incomum da "gente de nação” em empregá-lo. Já na Proposta que faz a d. João IV, em julho de 43, Vieira sugeria-lhe que:

Se vossa majestade for servido de os favorecer e chamar, será Lisboa o maior império de riquezas, e crescerá brevissimamente todo o reino a grandíssima opulência, e se seguirão infinitas comodidades a Portugal, juntas com a primeira e principal de todas, que é a sua conservação. ${ }^{26}$

O gênio comercial único que supõe nos judeus é descrito, à sua maneira, através da equivocação da palavra "inteligência", usada com o sentido de "indústria", isto é, como capacidade de ajustar vantajosamente necessidade e custo, e também com o de "entendimento secreto", vale dizer, como probabilidade de ter notícias confiáveis e recentes sobre as políticas econômicas dos mais diferentes reinos, por meio de uma rede de informações estabelecida entre a gente de nação em todo o mundo. É o que escreve no mesmo Papel:

Ajudar-se-á também vossa majestade da inteligência destes homens, porque não só por sua indústria se podem trazer das nações estrangeiras por muito acomodado preço as coisas necessárias para a guerra, mas também por suas inteligências secretas se poderão saber os desígnios e granjear as notícias dos reinos estranhos, sem as quais se não pode bem governar o próprio. ${ }^{27}$

E conclui a mais invariável de suas conclusões, a par do emprego católico da razão de Estado:

Enfim, senhor, Portugal não se pode conservar sem muito dinheiro, e para o haver, não há meio mais eficaz, que o do comércio, e para o comércio não há outros homens de igual cabedal e indústria aos de nação. ${ }^{28}$

De fato, até onde vejo, há algo de arraigadamente étnico na maneira de Vieira conceber "os negócios", ou "o dinheiro", termos que entende 
fundamentalmente no interior da riquíssima semântica do judeu. Por isso mesmo, nessa concepção, há muito de arcaico e de estranho ao mundo burguês - diferentemente do que dizem os que gostam de pensá-lo como autor avant la lettre, no caso, antecipador de tendências ilustradas ou revolucionárias. A meu ver, engana-se também um crítico, de resto admirável, como Otto Maria Carpeaux, que o pensa de um ponto de vista em que o século XVII funciona como "época de transição", e, a partir daí, interpreta as "pompas monárquico-religiosas", que tipifica sob a rubrica de "Barroco", como "espécie de pseudomorfose do aburguesamento". ${ }^{29}$ É nessa perspectiva que pode concluir que, como horizonte, "o verdadeiro Encoberto do sebastianista Vieira seria o burguês" ${ }^{30}$

Para discordar desse viés interpretativo - e deixando de lado a impropriedade específica da aplicação do termo "sebastianista" a Vieira —, basta ver que o jesuíta jamais percebeu que o capital tem determinações materiais próprias e, enfim, é surdíssimo à sereia sutil da teologia. Com efeito, apenas quem jamais admitiu a autonomia das produções econômicas, num mundo que crê sacramentado com a presença de Deus, julgaria poder convencer o capital a aplicar-se aqui ou ali, confiantemente, com o seguro exclusivo das especulações proféticas. Um seguro, aliás, cujo único fundo era, e é ainda, o gênio da língua — ou da lábia, como bem assinalava o próprio d. João IV, diante das razões indisputáveis alegadas por seu valido.

Seja como for, os autos do processo inquisitorial deixam ver que a formulação profética do VImpério fornece a sustentação teológica da assertiva política. $\mathrm{Ou}$, para ser mais preciso, acomoda aspectos importantes da crença judaica ao catolicismo a fim de que os judeus convençam-se do interesse de tornar a Portugal, e de que os portugueses, por sua vez, admitam o valor cristão e também político-econômico dessa convivência. Penso que, muito sinteticamente, as profecias de Vieira moldam-se no interior desse quadro. Ele as fabrica com o mesmo tipo de convicção que argumenta sobre a conveniência da reforma nos estilos da Inquisição para obter o investimento de recursos da "gente de nação" no Estado falido e, ao mesmo tempo, para afastar os "escrúpulos" e os supostos "inconvenientes” cristãos em aceitá-lo. Para ele, nada pode ser mais fiel à doutrina do 
Evangelho do que esse ajuste salvífico, o qual chamou certa vez, escrevendo a d.João IV, de dissimulação da cizânia:

(...)Cristo Senhor nosso falando em próprios termos, aconselha que se deve dissimular a cizânia para sustentar as raízes do trigo, entendendo por cizânia os infiéis, e por trigo os católicos, como afirmam todos os doutores; e no mesmo lugar repreende o Senhor, o falso e mal entendido zelo, dos que, com perigo da conservação do trigo, queriam arrancar a cizânia e mandou que a deixassem estar e crescer, junto da mesma seara. ${ }^{31}$

Mas, segundo creio, seria equivocado chamar a essa construção exegética conciliatória de "ideologia", no sentido de "falsa consciência": não se trata de fantasiar um lado, o teológico e profético, para disfarçar ou dourar a pílula do outro, o político e econômico. Não fora a evidente e sincera crença na finalidade cristã possível dos empregos judaicos, é inconcebível que Vieira tomasse manifestamente o lugar do capital como objeto de uma exegese tão ousada, disputada segundo os procedimentos e lugares da própria tradição exegética. $\mathrm{Ou}$, ainda mais, seria improvável que aplicasse anos de sua vida, dois dos quais recluso em uma cela, a reclamar pena e tinta para elaborar explicaçóes magnificamente complexas, às quais, contudo, não votasse valor algum. Ora, muito pelo contrário, Vieira julgava-as matérias "novas e não vulgares", capazes de "abrir novos fundamentos" da verdade e possíveis de ser tratadas apenas após os seus "quarenta anos de estudo" das Sagradas Escrituras, buscando nelas, como diz, "não as flores senão as raízes e trabalhando por alcançar o verdadeiro, genuíno e literal sentido com que foram escritas e ditadas pelo Espírito Santo". ${ }^{2}$

O verossímil, pois, é que Vieira julgava o assunto gravíssimo e digno de um Concílio inteiro da Igreja, o que, aliás, escreve com todas as letras na Petição ao Conselho Geral do Tribunal do Santo Ofício, de 21 de setembro de 1665:

E algum houve que considerando a grandeza e importância de muitas das ditas matérias e a utilidade que do conhecimento delas se pode seguir à universal Igreja e à conversão de muitas almas de Ateus, Gentios, Judeus, e de todo o outro gênero de infiéis, e hereges, julgou e disse que eram merecedoras as ditas matérias, de que na Igreja se fizesse um Concílio para maior qualificação delas. ${ }^{33}$ 
Além disso, é notório que bastaria abdicar da discussão dessas questôes para abreviar o processo inquisitorial e ver-se logo restituído ao beiramar de que sua saúde parecia depender. E o jesuíta simplesmente não o faz, a despeito de todo o sangue que alega cuspir, dia após dia.

Vieira, sem dúvida, acreditava na alta qualidade teológica, não apenas política, de suas interpretaçôes proféticas. Acreditava na providência do dinheiro, no desígnio divino dos negócios. O "dinheiro" de que fala não é o mesmo do burguês: longe de laico, é tão encoberto e sobrenatural quanto o seu Vice-Cristo ou a Eucaristia. As suas exegeses do futuro eram ato verdadeiramente beato de construção da sustentação teológica, necessária e inalienável do plano de fortalecimento do Estado católico moderno e da Igreja Romana. Com isso, buscava igualmente convencer os "homens de negócio", como ele próprio estava convencido, de que o melhor fundo para aplicação de seu cabedal passava pelo arruinado reino de Portugal.

Por outro lado, pelo que se disse acima, vê-se como o Tribunal andava equivocado no tocante à atribuição de culpa de "maquiavelismo" a Vieira. O tour-de-force profético-econômico mostra suficientemente que ele participa da mentalidade, ou da linguagem comum a ele e aos inquisidores, que não reconhecia uma razão autônoma ao governo e ainda menos ao comércio ou ao dinheiro. Ora, as praças de França, Holanda e Inglaterra, às quais mais acorriam comércio e dinheiro, sabiam-se dispensar das distinçôes escolásticas para buscar modos próprios e consistentes de multiplicar-se. Estavam bastante cientes das atrações efetivas do mercado que se firmava - , não importa o que mais demonstrasse o engenho dos oradores. Assim, a crença infinita de Vieira no poder de germinação da palavra cuja semente é Deus, o seu esforço para especificar os distinguos teológicos, os quais, por sua vez, coexistem com um conhecimento apenas superficial das soluções produzidas pelo jogo burguês da economia, demonstra de sobejo a verdade não ambígua do seu catolicismo militante, contrário em tudo à autonomização das razões materiais, presente no capitalismo.

Bem pesadas as coisas, portanto, a condenação sofrida pelas idéias de Vieira na rede das qualificações do Santo Ofício não tem a ver propriamente com um capítulo do fracasso ou da hesitação no avanço do espírito burguês na Península. O jesuíta não serve como figura da consciência pré- 
iluminista barrada pelo obscurantismo inquisitorial, mas, se quisermos, é adequado atribuir-lhe a consciência de um homem de fé militante que defende a hegemonia do Estado Católico, e cuja estratégia passa necessariamente pela acomodação das diferenças étnico-religiosas no seio da Monarquia temporal. A exegese do capital é, pois, parte essencial dessa estratégia, e, a rigor, tomado como matéria exegética, evidencia-se que "capital” é termo anacrônico à questão de Vieira. Nesse sentido, a sentença do Tribunal controlado por dominicanos revela sobretudo contradições internas ao catolicismo do final do XVII, quando dispersa-se o espírito da unidade contra-reformista em disputas nacionais e paroquiais. Além disso, neste momento, já são muitas as dificuldades de se tomar um partido claro frente às tradiçôes místicas e costumes variados com que vai-se defrontando o próprio desdobramento internacional da sua militância. Agora, a anterior unidade contra-reformista fica obrigada a reinterpretar-se por esse mesmo contingente de crenças e práticas diversas, de modo a alcançar contornos mais flexíveis e acomodatícios, enfim, mais persuasivos. Isto, claro, desde que insista em sua vocação de política católica, isto é, universal. Vieira, é certo, insistia: tão certo quanto depois do quarto vem o quinto.

\section{Notas}

${ }^{1}$ Os Autos do Processos de Vieira na Inquisição, ed. A.F. Muhana, São Paulo/Salvador, Unesp/ Fundação Cultural do Estado da Bahia, 1995; p. 106.

${ }^{2}$ Idem, p. $400-1$.

${ }^{3}$ Tais rascunhos foram editados em Lisboa, com edição de A.F. Muhana, sob o título de Apologia das coisas profetizadas (Livros Cotovia, 1994).

${ }^{4}$ Os Autos..., op. cit., p. 112.

${ }^{5}$ Idem, p. 401.

${ }^{6}$ Editada em dois volumes por Hernani Cidade, em 1957, na Bahia, pela Livraria Progresso.

${ }^{7} \mathrm{O} 27^{\circ}$ Exame (p. 308-14 dos Autos, op. cit.) é o que talvez melhor resume todas essas formulaçōes.

${ }^{8}$ Idem, op. cit., p. 327.

${ }^{9}$ Idem, p. 330.

${ }^{10}$ Lisboa, Seabra \& Antunes, 1856-7, em dois volumes. O comentário encontra-se à p. 173 do $1^{\circ}$ volume. 
${ }^{11}$ Cf. João Lúcio de Azevedo, História de António Vieira, vol. II, p. 67-8, da 3a ed. da Clássica Editora (Lisboa, 1992).

${ }^{12}$ Os Autos..., op. cit., p. 372.

${ }^{13}$ Idem, p. 408.

${ }^{14}$ Idem, p. 311.

${ }^{15}$ São termos presentes, por exemplo, no Exame 24, de 14 de maio de 67; in: Autos..., op. cit., p. 279.

${ }^{16}$ Idem, ibidem.

${ }^{17} \mathrm{O}$ documento está transcrito no artigo de Mário Nunes Costa, Fr. Teodósio da Cunha, qualificador do Pe. António Vieira em 1729, in Arquivo de Bibliografia Portuguesa, Coimbra, 1(2), 1955.

${ }^{18}$ Idem, p. 43.

${ }^{19}$ Idem, p. 44.

${ }^{20}$ Idem, p. 45.

${ }^{21}$ Idem, ibidem.

${ }^{22}$ Idem, ibidem.

${ }^{23}$ Autos..., op. cit., p. 442.

${ }^{24}$ Idem, p. 310.

${ }^{25}$ Idem, p. 310-11.

26 "Proposta feita a El-Rei D. João IV em que se lhe representava o miserável estado do reino e a necessidade que tinha de admitir os judeus mercadores que andavam por diversas partes $d a$ Europa pelo Padre Antônio Vieira" in Escritos Históricos e Políticos, São Paulo, Martins Fontes, 1995. Citação à p. 292-3.

${ }^{27}$ Idem, p. 293.

${ }^{28}$ Idem, p. 294.

29 "Aspectos ideológicos do Padre Vieira" in: Sobre Letras e Artes, organizado por Alfredo Bosi; São Paulo, Nova Alexandria, 1992. Citação à p. 56.

${ }^{30}$ Idem, p. 58.

31 "Proposta feita a el-rei D.João IV (...)", op. cit., p. 296.

32 "Petição ao Conselho Geral da Inquisição portuguesa, in: Os Autos..., op. cit., p. 120.

${ }^{33}$ Idem, p. 125.

\section{Bibliografia}

AZEVEDO, João Lúcio de. História de António Vieira. Lisboa : Clássica, 1992, 3a. ed. 
COSTA, M. N. [Frei Teodósio da Cunha]. Arquivo de bibliografia portuguesa (Coimbra), v. 1, n.2, 1955.

Os Autos do processo de Vieira na Inquisição. Transcrição e organização de A. Muhana. S. Paulo/Salvador: UNESP e Fund. Cult. do Estado da Bahia, 1995.

PÉCORA, Alcir. Teatro do Sacramento. São Paulo : Edusp, 1995

VIEIRA, Antonio. Obras Inéditas do Padre António Vieira. Lisboa: Seabra \& Antunes, 1856-57. 2 vols. - Apologia das coisas profetizadas. Lisboa : Cotovia, 1994. . Escritos históricos e politicos. Organização de Alcir Pécora. São Paulo : Martins Fontes, 1995.

\section{Resumo}

O ENSAIO INVESTIGA, numa primeira parte, os principais pontos debatidos nas trinta sessôes de interrogatórios do jesuita Antônio Vieira (1608-1697) no Santo Oficio de Coimbra; numa segunda parte, procura demonstrar que as posiçôes contrárias têm pressupostos teológicos comuns e que as opinióes de Vieira, diferentemente do que se tem difundido muitas vezes, não podem ser tomadas como protoiluministas ou protoburguesas.

\section{Abstract}

IN THE FIRST PART OF THIS ARTICLE, the author analyzes the interrogation of the Jesuit Antônio Vieira (1608-1697) during his trial by the Holly Office. In the second part, the author describes the theological Vieira's thought and argues against the interpretations that they represent forerunners of ideas later to be developed by the Illuminism and by the bourgeoisie. 